\title{
Maternal Mortality in Cordoba City, Argentina: Causes, Determinants and Trends
}

\author{
Mary Eugenia Peisino ${ }^{1}$, Rudolph Gomez Ponce de León ${ }^{2,}$, , Marie Jo Demaría ${ }^{1}$, Alice Díaz ${ }^{1}$, \\ Gabriel Acevedo ${ }^{1}$
}

${ }^{1}$ School of Public Health, National University of Córdoba, Córdoba, Argentina

${ }^{2}$ Latin American Center for Perinatology, Women's Health and Reproductive Health (CLAP SMR), Pan American Health Organization/World Health Organization, Montevideo, Uruguay

\section{Email address:}

eugepeisino@hotmail.com (M. E. Peisino), gomezr@paho.org (R. G. P. de León), mariajosezanier@yahoo.com.ar (M. J. Demaría), alice.sdiaz@gmail.com (A. Díaz), gabrieleacevedo@gmail.com (G. Acevedo)

*Corresponding author

\section{To cite this article:}

Mary Eugenia Peisino, Rudolph Gomez Ponce de León, Marie Jo Demaría, Alice Díaz, Gabriel Acevedo. Maternal Mortality in Cordoba City, Argentina: Causes, Determinants and Trends. Science Journal of Public Health. Vol. 8, No. 1, 2020, pp. 1-7. doi: $10.11648 /$ j.sjph.20200801.11

Received: July 24, 2019; Accepted: September 6, 2019; Published: January 16, 2020

\begin{abstract}
Background: The improvement of maternal health and reduction of maternal mortality have been a priority on the global community's agenda. In this sense, the "plan of action to accelerate the reduction of maternal mortality and severe maternal morbidity" has focused on improving women's health and attempted to contribute to the efforts of different countries to meet the fifth Millennium Development Goal (MDG 5). As the member states committed to achieving the MDGs, a considerable decline in maternal mortality was noted across the Region. The aim of the present work was to investigate maternal mortality rates in the city of Cordoba between 2008 and 2017. In addition, the study aimed analyzing the causes associated with maternal mortality and determining the sociodemographic profile of maternal deaths from direct and indirect causes in the 2015-2017. Methods: A descriptive, retrospective study was performed. Secondary data sources obtained from official publications were searched, especially those produced by the Mother-Child Bureau, the Department of Provincial Statistics, and the Municipal Epidemiology Center. Results: During the period from 2008 to 2017, a declining MMR trend was observed in the city of Cordoba, with a $26.8 \%$ decline from $31.2 \%$ in 2008 to $22.9 \%$ in 2017 . Analysis of the causes of maternal death showed that in 2015-2017 most corresponded to direct causes (56\%), followed by indirect causes (38\%) and abortion (6\%). These data agree with the latest report by the Ministry of Health in Argentina (57\% of direct causes). Cordoba city has experienced a substantial decline in MMR, and that maternal deaths account for only a small percentage of overall deaths in the city. Conclusions: Nevertheless, maternal deaths occurred in a population that is usually healthy and are mostly avoidable with well-known interventions. Therefore, it is essential to adequately characterize this public health problem, to strengthen public policies targeting the reduction of maternal mortality and severe maternal morbidity, as well as the optimal care of women during pregnancy and childbirth.
\end{abstract}

Keywords: Maternal Mortality, Determinants, Causes, Cordoba City, Avoidable Maternal Deaths

\section{Introduction}

Maternal death, a consequence of inequalities faced by women of reproductive age, has adverse implications for the family and society. This catastrophic event is the product of a set of socioeconomic determinants, especially economic and educational disadvantage and health-related factors such as access to and quality of reproductive health care services [1].

The improvement of maternal health and reduction of maternal mortality have been a priority on the global community's agenda. In this sense, the "plan of action to accelerate the reduction of maternal mortality and severe maternal morbidity" has focused on improving women's health and attempted to contribute to the efforts of 
different countries to meet the fifth Millennium Development Goal (MDG 5) [2]. As the member states committed to achieving the MDGs, a considerable decline in maternal mortality was noted across the Region. In Latin America and the Caribbean, maternal mortality decreased 40\% between 1990 and 2013, slightly below the world average (45\%), and also below the $75 \%$ target established by the MDGs. Nonetheless, the maternal mortality ratio (MMR) in the region was of 85 deaths per 100,000 live births [3].

More recently, the commitment to reduce maternal mortality has been ratified with the inclusion in the Sustainable Development Goals (SDGs) and in the Global Strategy for Women's, Children, and Adolescent's Health (2016-2030) [4] of a target to reduce the MMR to less than 70 deaths per 100,00 live births globally [3]. Considering that the region of the Americas already had a lower MMR $(62 / 100,000)$ in 2010, the Pan American Health Organization (PAHO) divided member countries into four groups with specific targets regarding SDG 3, according to their MMR in 2010. Argentina (MMR $58 / 100,000)$ was placed in group 3 , with an expected average annual decline (AAD) of -2.6 to achieve an MMR of 35.2 in year 2030 [3].

The variety of factors associated with the almost always avoidable maternal deaths complicates health actions geared towards reducing them, as well as the achievement of the expected results. Such factors include living conditions, income and education, among others, and also factors linked to the access and quality of health care services. Therefore, it is necessary to identify the factors underlying the issue of maternal mortality to determine which areas should be targeted to allow achievement of the sanitary goals proposed and agreed upon both locally and regionally [3].

Taking these aspects into consideration, the present study was set in the city of Cordoba, Argentina. Cordoba is capital of the homonymous and second most populous province in Argentina, with demographic characteristics and sanitary conditions that well represent the determinants of maternal morbidity and mortality. The city of Cordoba is the largest city in Argentina terms of territory, and the second in Latin America, with a population of $1,318,154$, projected at $1,430,00$ in 2017 [5]. Women account for $52.29 \%$ of this population. The city's population pyramid reflects the changing age structure of the world population, even though a major widening is observed in the 20 to 24-year age group, explained by youth migrating to this area to attend university and for academic development, coming from other provinces and other countries.

Thus, the objective of the present work was to investigate maternal mortality rates in the city of Cordoba between 2008 and 2017. In addition, the study aimed at investigating the causes associated with maternal mortality and determining the sociodemographic profile of maternal deaths from direct and indirect causes in the 2015-2017 triennium, for which better quality information was available.

\section{Materials and Methods}

A descriptive, retrospective study was performed. Secondary data sources obtained from official publications were searched, especially those produced by the MotherChild Bureau (under the Cordoba Province Health Ministry), the Department of Provincial Statistics, and the Municipal Epidemiology Center (under the City of Cordoba Epidemiology Bureau) [6].

Based on the official information available, the evolution of maternal mortality was analyzed in Cordoba for the 10year period from 2008 to 2017. Data regarding births and maternal deaths for the period of interest were obtained from the Province of Cordoba Health Information and Statistics Bureau [7].

In 2015, the City Epidemiology Bureau began to publish maternal death surveillance data for the city of Cordoba. Thus, more information is available for this specific period (2015-2017), with disaggregated data obtained directly from the city's civil death registration system. The causes of death obtained from the death certificates were classified in the present study according to the International Classification of Diseases (ICD-10) [8].

Regarding the sociodemographic profile of women who died from maternal causes, the following information was available for the 2015-2017 triennium from death certificates: age, place of residence, highest level of educational attainment, occupation, coverage by private health insurance, and place of death. The variable highest level of educational attainment was expressed according to the following categories: low - complete primary education and incomplete secondary education; medium - complete secondary education and incomplete post-secondary education/university education; high - post-secondary or university degree. Occupation was categorized into formal and informal employment (encompassing women who did not work, those with informal employment, and those managing the household).

The three delays model proposed by Thaddeus S, Maine D [12] was used. According to this model, the interval between the start of an obstetric complication and treatment may contribute to maternal death. Three types of delay are considered: delay by the woman or the family to recognize warning signs and leave the household to seek the health care system; delay reaching the health care facility; and delay originating within the health care system itself, i.e., delay in providing timely and effective life-saving care [9].

Based on the information obtained, descriptive analyses were performed, with calculation of epidemiologic indicators, trend plots, and geolocation of cases and health care facilities.

\section{Results}

During the period from 2008 to 2017, a declining MMR trend was observed in the city of Cordoba (figure 1), with a $26.8 \%$ decline $(31.2 \%$ in 2008 to $22.9 \%$ in 2017 ). Along these 10 years, inter-year variation was detected, with a peak 
of deaths in year 2009 ( $\mathrm{n}=16)$, during the H1N1 influenza epidemic in Argentina.

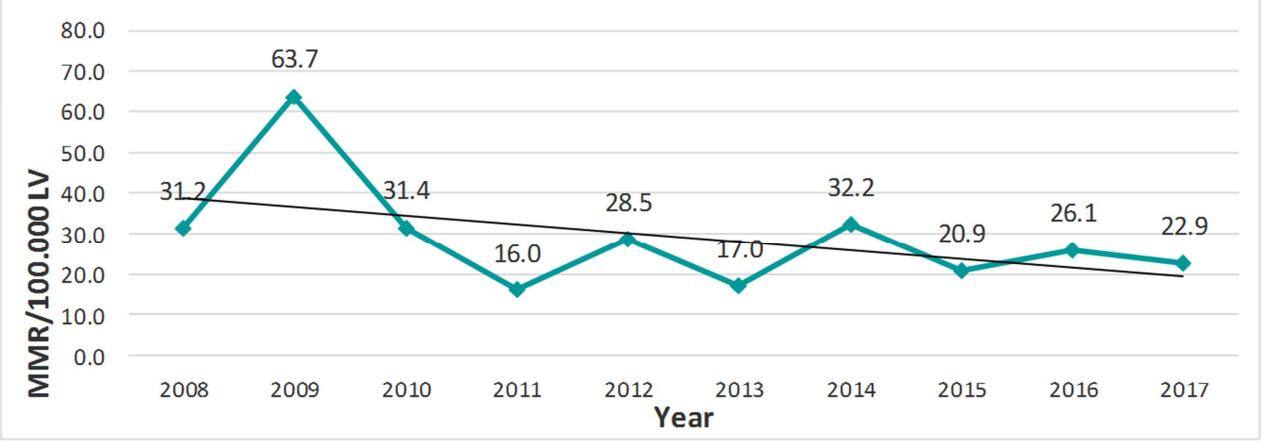

Maternal Mortality Rate trend line

Figure 1. Evolution of maternal mortality ratio in Cordoba city, Argentina, per 100,000 live births, 2008-2017 Source: Dirección de Epidemiología Secretaría de Salud, Municipalidad de Córdoba.

During the period between 2015 and 2017, 16 maternal deaths were recorded. As shown in table 1, these deaths resulted from direct obstetric causes in nine cases $(56 \%)$ and from indirect obstetric causes in six cases (38\%). In one case, the cause of death was recorded as abortion (6\%). Each of the causes of death recorded in the death certificate are also described. The most frequent cause of death was diseases of the respiratory system complicating pregnancy, childbirth, and the puerperium (19\%), followed by amniotic fluid embolism (13\%) and other specified diseases and conditions complicating pregnancy, childbirth, and the puerperium $(13 \%)$.

Table 1. Number of maternal deaths according to group of causes and ICD-10 classification in Córdoba city, 2015-2017.

\begin{tabular}{|c|c|c|c|c|c|c|c|c|c|}
\hline \multirow{3}{*}{$\begin{array}{l}\text { Code } \\
\text { ICE } 10\end{array}$} & \multirow{3}{*}{ Cause of Death } & \multicolumn{6}{|c|}{ year } & \multirow{2}{*}{\multicolumn{2}{|c|}{$\begin{array}{l}\text { Total Maternal } \\
\text { Deaths 2015-2017 }\end{array}$}} \\
\hline & & \multicolumn{2}{|c|}{2015} & \multicolumn{2}{|c|}{2016} & \multicolumn{2}{|c|}{2017} & & \\
\hline & & $\mathbf{N}$ & $\%$ & $\mathbf{N}$ & $\%$ & $\mathbf{N}$ & $\%$ & $\mathbf{N}$ & $\%$ \\
\hline \multicolumn{10}{|c|}{ DIRECTAS } \\
\hline O881 & Amniotic fluid embolism & 1 & 6 & 1 & 6 & & & 2 & 13 \\
\hline $\mathrm{O} 722$ & Delayed and secondary postpartum hemorrhage & & & 1 & 6 & & & 1 & 6 \\
\hline $\mathrm{O} 723$ & Pospartum coagulation defects & & & 1 & 6 & & & 1 & 6 \\
\hline O730 & Retaired placenta without hemorrhage & & & & & 1 & 6 & 1 & 6 \\
\hline O868 & Other specified puerperal infections & 1 & 20 & & & & & 1 & 6 \\
\hline O903 & Cardiomyopathy the puerperium & & & & & 1 & 6 & 1 & 6 \\
\hline 0888 & Other obstetrics embolism & & & & & 1 & 6 & 1 & 6 \\
\hline O75 & Other complications of labor and delivery not elsew here classified & & & & & 1 & 6 & 1 & 6 \\
\hline \multicolumn{2}{|r|}{ Subtotal maternal deaths from direct causes } & \multicolumn{7}{|c|}{ ABORTION } & 56 \\
\hline O065 & Complete or unspecified complicated by genital tract and pelvic infection. & & & & & 1 & 6 & 1 & 6 \\
\hline \multicolumn{9}{|c|}{ INDIRECT } & 6 \\
\hline O995 & $\begin{array}{l}\text { Diseases of the respiratory system complicating pregnancy, childbirth and the } \\
\text { puerperium. }\end{array}$ & 1 & 6 & 2 & 13 & & & 3 & 19 \\
\hline O998 & $\begin{array}{l}\text { Other specified diseases and conditions complicating pregnancy, childbirth, and } \\
\text { the puerperium. }\end{array}$ & 1 & 6 & 1 & 6 & & & 2 & 13 \\
\hline O996 & $\begin{array}{l}\text { Diseases of the digestive, system complicating pregnancy, childbirth and the } \\
\text { puerperium. }\end{array}$ & 1 & 6 & & & & & 1 & 6 \\
\hline \multirow{2}{*}{\multicolumn{2}{|c|}{$\begin{array}{l}\text { Subtotal Maternal deaths from indirect causes } \\
\text { ALL CAUSES }\end{array}$}} & 3 & 19 & 3 & 19 & & & 6 & 38 \\
\hline & & 5 & 31 & 6 & 38 & 5 & 31 & 16 & 100 \\
\hline
\end{tabular}

Source: Dirección de Epidemiología - Secretaría de Salud, Municipalidad de Córdoba.

The mean age of deceased women in the study period was 31 years (18 to 43 years). The group of women younger than 20 years of age corresponded to $6 \%$ of all deaths. The remaining 35 years $(44 \%)$.

Analysis of the place of residence deaths were distributed as follows: 8 in the group from 20 to 34 years $(50 \%)$ and the rest in women aged $\geq$ showed that none of the deceased women lived in the city center, despite this being the most densely populated area in the city. Nevertheless, $75 \%$ of the cases lived within the city's outer ring-road in areas considered as highly urban.

Regarding maternal deaths, considering the three delays, it was observed that $31.25 \%$ of the deaths $(n=5)$ were associated with the first delay, that is, delay in deciding to seek care. The remaining $68.75 \%(\mathrm{n}=11)$ corresponded to the third delay, that is, delay in receiving adequate and timely 
care. There were no cases linked to the second delay, that is, delay in reaching a health care facility. In fact, by applying to the geolocation of each case a 1,000-m diameter circle to evaluate access to health care services (second delay), [10] it was determined that all deaths occurred in areas with access to health care providers. In all cases, there was a primary health care center less than 1,000 $\mathrm{m}$ away from the deceased women's household (Figure 2).

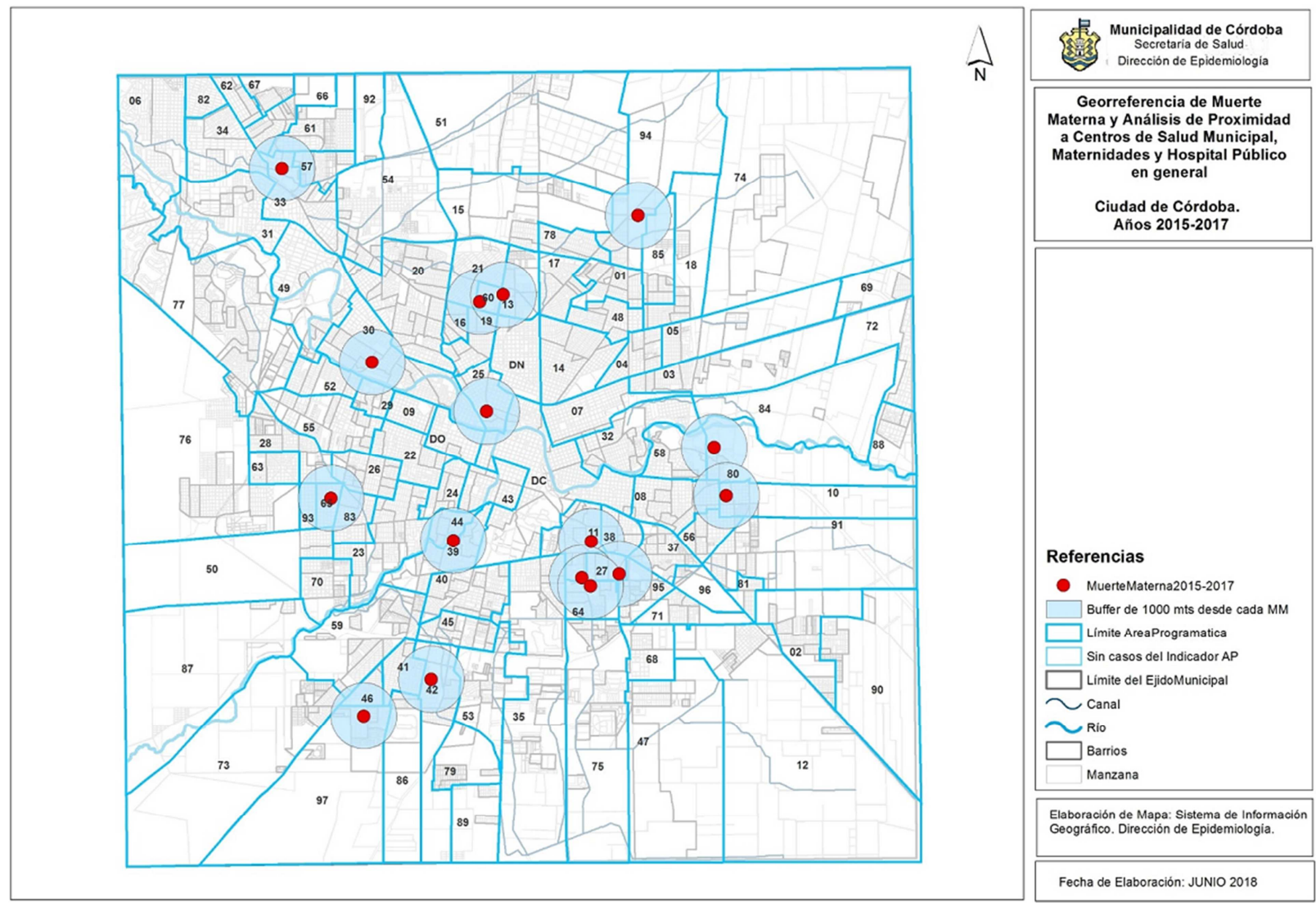

Source: Dirección de Epidemiología, Secretaría de Salud, Municipalidad de Córdoba.

Figure 2. Geolocation of maternal deaths in Cordoba city, Argentina, 2015-2017.

Regarding educational attainment, table 2 shows low attainment in $63 \%(\mathrm{n}=10)$ of the sample, medium attainment in $31 \%(n=5)$, and high attainment in only $7 \%(n=1)$. Data on occupation were available for 14 of the 16 deceased women. Of these, $50 \%$ were formally employed, and the remaining
$50 \%$ were not. In terms of health insurance, $56 \%$ were covered by some kind of insurance. For seven women, the source of coverage was the woman's own formal job. In the other cases, coverage was available through a family member (Table 2).

Table 2. Maternal mortality and social determinants, city of Cordoba, Argentina, 2015-2017.

\begin{tabular}{|c|c|c|c|c|c|c|c|c|c|c|c|c|c|c|}
\hline \multirow{3}{*}{$\begin{array}{l}\text { Total maternal } \\
\text { deaths }(2015- \\
2017)\end{array}$} & \multicolumn{6}{|c|}{ Level of educational attainment } & \multicolumn{4}{|c|}{ Occupation status } & \multicolumn{4}{|c|}{ Health insurance } \\
\hline & \multicolumn{2}{|c|}{ Low } & \multicolumn{2}{|c|}{ Medium } & \multicolumn{2}{|c|}{ High } & \multicolumn{2}{|c|}{ Formal employment } & \multicolumn{2}{|c|}{$\begin{array}{l}\text { Informal employment or } \\
\text { does not work }\end{array}$} & \multicolumn{2}{|c|}{ Yes } & \multicolumn{2}{|c|}{ No } \\
\hline & $\mathbf{N}$ & $\%$ & $\mathbf{N}$ & $\%$ & $\mathbf{N}$ & $\%$ & $\mathbf{N}$ & $\%$ & $\mathbf{N}$ & $\%$ & $\mathbf{N}$ & $\%$ & $\mathbf{N}$ & $\%$ \\
\hline 16 & 10 & 63 & 5 & 31 & 1 & 6 & 7 & 50 & 7 & 50 & 9 & 56 & 7 & 44 \\
\hline
\end{tabular}

Source: Dirección de Epidemiología - Secretaría de Salud, Municipalidad de Córdoba.

Analysis of the place of death revealed that all deaths occurred in health care facilities: $44 \%(n=7)$ in public health care facilities and $56 \%(n=9)$ in private facilities. There were no maternal deaths in the household or before reaching the health care facility.

\section{Discussion}

Like Argentina and the province of Cordoba, the city of
Cordoba has witnessed a declining trend in MMR in the past 10 years, despite some oscillation, with a peak of 64per 100,000 live births in 2009. In that year, an increase in MMR was noted throughout the country, resulting mainly from the H1N1 influenza a pandemic [11].

The percent decline in MMR detected between 2008 and $2017(26.8 \%)$ in the city of Cordoba is considerably higher than that observed for the overall province $(17.73 \%)$ and country (15.11\%) [9]. A similar decline in MMR was 
recorded globally (44\% over a 25-year period, from 1990 to 2015) [3].

The declining trend in maternal mortality may be explained by comprehensive public policies focusing on the achievement of human development and equity [12]. Along with the implementation of these policies, during the study period, improvement in various indicators were recorded in the city of Cordoba - not only indicators that are directly associated with health care services, such as child mortality and percent health care coverage, abut also indicators associated with economic activity, such as employment rate, percentage of school enrolment, percentage of population with access to potable drinking water, natural gas, and basic sanitation, among others [13]. All these indicators impact and are closely linked to maternal mortality, which in turn is a very sensitive indicator of human development $[14,15]$.

Analysis of the causes of maternal death showed that in 2015-2017 most corresponded to direct causes (56\%), followed by indirect causes $(38 \%)$ and abortion $(6 \%)$. These data are in agreement with the latest report by the Ministry of Health in Argentina [13] (57\% of direct causes). The distribution of causes observed in the present work was also similar to that reported by other investigations performed in Latin American countries [16].

When maternal deaths were disaggregated by direct causes, a difference was observed between the three top causes found for the city of Cordoba as compared to Argentina and other Latin American countries [17] Whereas in the city of Cordoba the top three causes were diseases of the respiratory system complicating pregnancy, childbirth, and the puerperium (19\%), amniotic fluid embolism (13\%), and other specified diseases and conditions complicating pregnancy, childbirth, and the puerperium (13\%), in Argentina the three top causes were hypertensive disorders of pregnancy $(18.2 \%)$, complications of the puerperium, including puerperal sepsis (14.3\%), and hemorrhage (10.1\%) [15]. A similar distribution was found in Paraguay [17] (abortion, hemorrhage, and toxemia, with similar relative weights, around $20 \%$ each).

In $38 \%$ of the deaths due to indirect causes (women with a serious disorder that is complicated by pregnancy causing death) the timely and legal interruption of pregnancy would have saved the woman's life. Thus, is the duty of health care workers to present this choice so that the woman herself may exercise her autonomy and make a decision.

It should be noted that the data recorded and analyzed in the present study were those found in the individual death certificates of the deceased women, coded according to the ICD-10. It is clear that measurement of maternal mortality remains a challenge due to the deficiencies of official information systems, such as incomplete records, lack of active search for maternal deaths in the death certificates of women of reproductive age, and inappropriately completed death certificates. Many of these deaths are not accounted for, and the lack of reliable and timely data represent an obstacle for surveillance and decision-making to reduce them [18] Therefore, surveillance systems and the quality of the information must be strengthened as an essential tool that allows close, real-time follow-up of trends and actual causes of death [19]. To address this issue, the city of Cordoba has implemented a Maternal Morbidity and Mortality Surveillance Committee including various professionals who actively perform extensive surveillance of all deaths recorded in women aged 10 to 49 years. This has produced knowledge regarding the profile of maternal deaths and detection of three maternal deaths in the period from 2015 to 2017 (20\%) that had not been communicated as such by health care providers and therefore not recorded as such in the death certificate.

The mean age of the women who died from pregnancyrelated causes (31 years) reflects a group of young, economically active women, in agreement with the results of a 10-year study performed in Mexico, in which a mean age of 28.8 years was reported [20]. Conversely, a different mean age was reported by studies performed in other countries, for example Cuba. In that country, a study performed from 2001 to 2010 detected a mean age of 36 years for maternal deaths [21]. In the city of Cordoba, $7 \%$ of the deaths occurred in adolescents, which is lower $(-58 \%)$ than the $12 \%$ observed in Peru (Región La Libertad), vs. 29\% in women older than 35 years and $59 \%$ in women aged 20 to 35 years [22]. When age was linked to the cause of death, we found that the 18 -year old woman died from post-partum hemorrhage; the 43-year old women died of placenta accreta, which could also qualify as post-partum hemorrhage. All the women whose cause of death was diseases of the respiratory system complicating pregnancy, childbirth, and puerperium (major cause of death in the city of Cordoba, accounting for $20 \%$ of deaths) were in the 20 to 34 year-age group.

Regarding place of death, none of the deceased women lived in the city center, but $75 \%$ lived in highly urban areas. The deaths occurred in areas with adequate health care coverage, and none of the households was more than $1,000 \mathrm{~m}$ away from a primary health care provider. Therefore, the second delay was not observed in the present study.

Many investigations have described an association between low educational attainment and higher risk of death during pregnancy, pointing out that less educated women may not recognize warning signs and thus take longer to seek health care (delay 1). This supports the need to focus on health education initiatives at the primary health care level, where patients receive prenatal care $[18,22]$. In the city of Cordoba, $63 \%$ of the deceased women had a low level of educational attainment - slightly more (55\%) than in Jalisco, Mexico (2006-2010) [16].

As noted by Thaddeus $\mathrm{S}$ and Maine $\mathrm{D}$ it is important to keep in mind that many women die in the hospital after having overcome barriers 1 and 2. The delivery of emergency obstetric care depends on several factors, including the number of trained workers, drug supply and availability, and the overall conditions of the facility. In addition, there is a crucial element - the delivery of care. A facility may have all the required staff and supplies, and still deliver poor health care. The fact that $68.25 \%$ of maternal deaths in the city of Cordoba correspond to the third delay should prompt the reassessment of practices and actions performed by the 
various providers in the health care network.

Regarding health care coverage, we observed that $56 \%$ of the women had some kind of insurance. This is important considering the low schooling level in this sample. Also, not having any health care insurance increases the risk of maternal death due perhaps to difficulties in timely access to health care facilities and may limit the ability of women to make decisions regarding their own health. This hypothesis should be investigated in future studies including maternal near miss cases.

There is sufficient evidence of a strong link between the rate of decline in maternal mortality and the improvement of political and economic conditions. As discussed in the context of Uruguay, [23] there was an important decline in maternal mortality resulting fundamentally from a decrease in deaths from abortion. However, the reduction of maternal mortality in the past decade also coincided with a period of decrease in poverty and improvement of the human development index in that country. Those findings support the notion that maternal mortality is directly linked to, and is a very sensitive indicator of, human development. This is clearly expressed in all social indicators that comprise the human development index, which has increased steadily in Uruguay along this period, parallel to the decline in maternal mortality [18].

\section{Conclusion}

The present study was able to show that the city of Cordoba has experienced a substantial decline in MMR, and that maternal deaths account for only a small percentage of overall deaths in the city. Nevertheless, maternal deaths occurred in a population that is usually healthy and are mostly avoidable with well-known interventions. We should keep in mind that maternal deaths impact families - it is known that child mortality increases in surviving children. It would be useful to analyze the women who survive pregnancy-related complications in the province of Cordoba, also considering that for each maternal death 20 cases of severe maternal morbidity are expected [24, 25]. Therefore, it is essential to adequately characterize this public health problem, so as to strengthen public policies targeting the reduction of maternal mortality and severe maternal morbidity, as well as the optimal care of women during pregnancy and childbirth.

\section{List of Abbreviations}

CLAP Latin American Perinatology Center

MDG 5 Fifth Millennium Development Goal

MMR Maternal mortality ratio

SDGs Sustainable Development Goals

PAHO Pan American Health Organization

AAD Average annual decline

ICD-10 Tenth edition of the International Classification of Diseases

H1N1 Subtype of the influenza virus

\section{Declarations}

\section{Ethics Approval and Consent to Participate}

We used public data, and our manuscript does not report on or involve the use of any animal or human data or tissue, this section is not applicable.

\section{Consent for Publication}

Our manuscript does not contain any individual person's data, for this reason it is not applicable.

\section{Availability of Data and Material}

All the data supporting findings can be found under the references $(5,6,7,11,13)$.

\section{Authors' Contributions}

MEP: built the final report of the manuscript, RGPL: developed the study protocol, elaborate first draft analysis and final corrections, MJD and $\mathrm{AD}$ participated in the first draft and subsequent versions of the manuscript and GA reviewed the full process and approved the final document.

\section{Competing Interests}

The authors declare that they have no competing interests.

\section{Acknowledgements}

Authors are grateful for the invaluable contribution provided Dr. Maria Victoria Bertolino, Family Health Consultant (PAHO Argentina), Dr. Bremen De Mucio, Regional PAHO Maternal Health Advisor, and Dr. Suzanne Serruya, Director of the Latin American Perinatology Center (CLAP) at PAHO, who contributed to the present manuscript with generosity and resolvability.

\section{References}

[1] Campero L, Walker D, Hernández B, Espinoza H, Reynoso S, Langer A. La contribución de la violencia a la mortalidad materna en Morelos, México. Vol. 248 ed. Salud Pública Mex. México; 2006.

[2] United Nations. United Nations Millennium Declaration [Internet]. Fifty-fifth session of the UN General Assembly. 2000 Sept. 13. New York. UN. 2000 Sept. 18 (Resolution A/RES/55/2) [cited 2011 Feb. 24]. Available from: http://www.un.org/millennium/declaration/ares552e. pdf.

[3] WHO, UNICEF, UNFPA, The World Bank \& The United Nations. Population Division. Trends in Maternal Mortality: 1990 to 2015. Ginebra, Suiza: WHO. 2014. Disponible: http://apps.who.int/iris/bitstream/10665/112682/2/978924150 7226_eng.pdf.

[4] ONU, Programa para el Desarrollo Sostenible. La Estrategia Mundial para la salud de la Mujer, el Niño y el Adolecente (2016-2030). Nueva York. EUA. 2016. Disponible: https://www.everywomaneverychild.org/images/EWEC_GS BROCHURE_ES_WEB.pdf. 
[5] INDEC: Instituto Nacional de Estadísticas y Censos de la Republica Argentina. Censo Nacional de Hogares y Personas. Buenos Aires. Argentina. 2010. Disponible: https://www.indec.gob.ar/.

[6] Municipalidad de Córdoba: Portal de Gobierno Abierto. Sala de Situación de Salud. Córdoba. Argentina 2018. Disponible: https://gobiernoabierto.cordoba.gob.ar/data/datosabiertos/categoria/salud.

[7] Ministerio de Salud de la Nación. DEIS: Dirección de Estadísticas e Información de Salud. Estadísticas Vitales. Buenos Aires. Argentina. 2018. Disponible: http://www.deis.msal.gov.ar/index.php/serie-5-estadisticasvitales/.

[8] OPS, OMS. CIE 10: Clasificación Estadística Internacional de Enfermedades y Problemas Relacionados con la Salud. Vol 1.10 ed. Washington, DC. EUA. 2013.

[9] Ramos S, Romero M, Karolinski A, Mercer R, Insua I. Las tres demoras que contribuyen a la mortalidad materna. Evid. Pract. ambul. 2005; 8: 143-145. Disponible: http://www.evidencia.org.ar.

[10] CEDES. Observatorio de Salud Sexual y Reproductiva. Modelos de Análisis de Morbi-Mortalidad Materna. Buenos Aires. Argentina. 2010. Disponible: http://www.ossyr.org.a r.

[11] Ministerio de Salud de la Nación. Dirección Nacional de Maternidad Infancia. Análisis de mortalidad materno-infantil en Argentina 2003-2012. Buenos Aires. Argentina. 2014. Disponible: http://msal.gov.ar.

[12] Thaddeus S, Maine D (1994) Too far to walk: maternal mortality in context. Social Science and Medicine 38 10911110 .

[13] Municipalidad de Córdoba. Córdoba una ciudad en cifras 2017. Guía estadística de la ciudad de Córdoba. Córdoba Argentina. 2017.2 Disponible: https:/gobiernoabierto.cordoba.gob.ar/media/datos/GUIA_C \%C3\%B3rdoba_una_ciudad_en_cifras_2017.pdf.

[14] Organización Panamericana de la Salud e Instituto Nacional de Salud de Colombia.Protocolo de vigilancia epidemiológica de la mortalidad materna. Bogotá: OPS, 2016. http://iris.paho.org/xmlui/bitstream/handle/123456789/33712/ 9789275319338-spa.pdf?sequence=1\&isAllowed=y.

[15] World Health Organization. Evaluating the quality of care for severe pregnancy complications: the WHO near-miss approach for maternal health. 1. Pregnancy complications. 2. Maternal health services. 3. Pregnancy outcome. 4. Maternal mortality. 5. Infant mortality. 2011. http://apps.who.int/iris/bitstream/handle/10665/44692/978924
1502221 eng.pdf;jsessionid $=$ C47373D37FDAEC7C3FBFDF B3227DE51C?sequence $=1$.

[16] Mejía M, Ortiz V, Laureano E, Alcántara E, López ME, Gil E. Aspectos sociales de la muerte materna: análisis de 5 años en el Hospital General de Occidente. Jalisco, México - Rev Chil Obstet Ginecol 2013; 78 (6): 419-424.

[17] Fantin M A; Zavattiero C. Evolución y desigualdades de la mortalidad materna en Paraguay; algunos desafíos para su reducción. Población y Desarrollo. 2016; 22 (43): 2-12. http://ri.conicet.gov.ar/bitstream/handle/11336/23434/CONIC ET_Digital_Nro.02285f07-8425-4a67-bd087ce40b60cab4_A.pdf?sequence $=2$ \&isAllowed $=y$.

[18] ONU: Organización de las Naciones Unidas- Informe de los Objetivos de Desarrollo del Milenio 2015- Nueva York. EUA. 2015. Disponible: http://www.un.org/es/millenniumgoals/pdf/2015/mdg-report2015_spanish.pdf.

[19] Organización Panamericana de la Salud, Instituto Nacional de Salud Colombia. Protocolo de vigilancia epidemiológica de la mortalidad materna. Bogotá: OPS, 2016.

[20] Hernández PJA, Ramos AG, López CA. Análisis de casos de muerte materna en un periodo de 10 años. Ginecol Obstet México 2007; 75: 61.

[21] Suárez GJA, Gutiérrez MM, Lorenzo GBC. Problematica de la muerte materna en Villa Clara. Rev Cubana Cir 2011; 50 (4): 28-35.

[22] Santos L, Luna Victoria F, González M. Mortalidad materna: factores determinantes modificables mediante políticas públicas en la región La Libertad. UCV Scientia 2010; 2 (1): 22-33.

[23] Briozzo L, Gómez Ponce de León R, Tomasso, G, Faúndes, A- Mortalidad materna total y asociada al aborto en los últimos 25 años en el Uruguay y su relación con políticas y acciones de protección de los derechos de la mujerInternational Journal of Gynecology and Obstetrics 2016; 134: 20-23 (Traducción).

[24] Gutiérrez Ramos M, Velásquez Pancca E. Morbimortalidad Materna. Revista Peruana de Ginecología y Obstetricia. 2017; 63 (3): 413-427.

[25] World Health Organization. Evaluating the quality of care for severe pregnancy complications: the WHO near-miss approach for maternal health. 2011. Disponible: http://apps.who.int. 